\section{Fauna of the Paraguayan Chaco Swamps.}

A SERIES of papers on the fauna of the tropical A swamps of the Paraguayan Chaco were read at the meeting of the Linnean Society on Jan. 3. Messrs. G. S. Carter and L. C. Beadle, in a preliminary paper, dealt with the relation of the fauna to the physico-chemical conditions of the environment. These swamps cover large areas of the plains to the west of the Paraguay River on the latitude of the southern tropic; those in the neighbourhood of the station of the South American Mission Society at Makthlawaiya $\left(58^{\circ} 19^{\prime} \mathrm{W} ., 23^{\circ} 25^{\prime} \mathrm{S}\right.$. ) were investigated. They are shallow, frequently dry, and are filled with much aerial vegetation in all parts. During eight months (October 1926-June 1927), observations were made at regular intervals of several characteristics of the water in the swamps. The most striking observations were: (1) The high temperature which the surface-layers of the water were sometimes found to reach $\left(42^{\circ} \mathrm{C}\right.$.) ; (2) the large quantities of phosphates always present (up to $10 \mathrm{mgm}$. per litre); (3) the low tension of dissolved oxygen, not more than $2-3$ c.c. per litre in the surface layers, while below the upper 4-6 in. there was scarcely ever more than $0 \cdot 2$ c.c. per litre during the hot weather. This low oxygen content is believed to be due partly to the poverty of the aquatic flora, partly to the great activity of decay at the high temperature, and partly to the absence of convection currents caused by the cooling of the surface layers at night. The behaviour and distribution of the fauna show that the shortage of dissolved oxygen in the water is the greatest bionomic factor.

Dr. R. Gurney submitted a report on the Branchiopoda of the expedition. Dr. Carter's collections include five species, of which three appear to be undescribed. Four of them are Conchostraca, and include the remarkable Cyclistheria histopi, which is found also in Africa, India, Ceylon, and Australia.

Mr. E. Meyrick discussed the Microlepidoptera which were collected. The nature of the region would probably not be very favourable to Microlepidoptera. The number of species in identifiable condition is 32 ; of these, 2 genera and 22 species are described as new. Of the remainder, 3 are horticultural pests introduced with their food-plants, 1 a widely spread American insect, 2 are found also in the Argentine, and 4 in the Amazon valley. The new species are generally of Guiana and Amazon types.

Messrs. Carter and Beadle described their observa. tions on the habits and development of Lepidosiren paradoxa. The subsoil of clay, which occurs everywhere in the parts of the Paraguayan Chaco inhabited by this fish, preserves water in the burrow used in dry weather, thus keeping its skin moist. Oxygen is normally absent from the water surrounding the nest of the Lepidosiren, and the manner in which the respiratory needs of the eggs and young larvæ are satisfied is discussed. The normal rhythm of the contraction of the pigment cells of the skin of the larvæ at dusk and their expansion at dawn is preserved for some days when the larvæ are kept in the dark continuously.

Dr. J. Stephenson dealt with the Oligochæta. Oligochæta have been collected from the northern and more remote part of Paraguay only twice previously, and then only in small numbers; hence the present collection contains a large proportion of new species. Limicoline forms are in the majority. A considerable part of the interest of the present collection lies in considerations of geographical distribution.

Dr. W. A. Cunnington reported on the Argulidæ of the expedition, which belong to the genera Dolops and
Argulus. The two species of Dolops-Dolops striatu (Bouvier) and Dolops geayi (Bouvier)-are of interest, as certain specimens are larger than any hitherto recorded. The single species of Argulus appears to be new to science.

Mr. H. W. Parker discussed the Amphibia and Reptilia which were collected. Dr. Carter's collections contain two tadpoles and a half-grown example of the frog Ceratophrys laevis (Budgett). The tadpoles, hitherto undescribed, have mouth-parts of a kind unique amongst the Salientia, and, as their food is exactly similar to that of some other species of Ceratophrys, this suggests that laevis is not closely genetically related to the other members of the genus in which it is at present included.

\section{University and Educational Intelligence.}

CAMbridge.-D. J. Watson, Downing College, has been appointed to the Frank Smart University Studentship in Botany. J. C. P. Miller, Trinity College, has been elected to the Sheepshanks Exhibition.

THE Chadwick Trustees invite applications from British subjects between twenty-five and thirty years of age who are graduates of a British university or of equivalent standing, for two travelling scholarships of $£ 400$ each, to enable the holders to travel abroad during one year to study methods adopted in other countries for the prevention of disease and the improvement of the public health. One scholarship will be for sanitary science and the other for municipal engineering. Applications must be sent in before Mar. 25 ; full particulars may be obtained from the Clerk of the Chadwick Trustees at 204 Abbey House, Westminster, London, S.W.1.

PARENT-TEACHER associations have so grown, says the United States Bureau of Education in the November issue of School Life, that they have become one of the outstanding forces in American education. Their members, numbering more than a million and a quarter, are organised under the guidance of the National Congress of Parents and Teachers, founded in 1897, for the promotion of a better understanding between parent and teacher with consequent cooperation between home and school and appreciation on the part of all citizens of their responsibility to the younger generation. The Congress executive operates, with the help of the teacher members, an ambitious scheme of adult education in which it has the powerful backing of the federal Bureau of Education, and last September it promulgated a manifesto urging the supreme importance of universal education for parenthood. In this document, which was published in the October issue of School Life, it calls upon universities and colleges to develop special courses in this subject in their teacher training, extension and correspondence study departments, exhorts public librarians to organise special facilities for its study, and State and city school officers to plan for bureaux of parent education. The Bureau of Education is supporting this movement by publishing a series of nine articles by eminent authorities concerning parent-teacher associations in their relation to the children and to the schools of elementary, secondary, and higher grade. The first of these, on the Congress programme of parent education, appears in the November issue of School Life. Others will deal with pre-school education, the teacher, the parent and the curriculum, recreation as a necessary part of home life, parents and the sex question, parents and highschool students, parents in higher education, books, and parent education in the home.

No. 3097, VoL. 123] 